\title{
EFFECT OF DIFFERENT NITROGEN SOURCES OF WHEAT AND
} MAIZE YIELDS

\author{
M.S. Awaad, M. A. El shazly, M. B. Taha and I. M. Abdalla \\ Soils, Water and Environment Res. Inst. (SWERI), Agricultural Research Center (ARC), \\ Giza, Egypt
}

Received: Sep. 17,2020

Accepted: Oct. 28,2020

\begin{abstract}
Two field experiments were carried out during winter season (2016/2017) and summer season (2017) an clay soil to evaluate the effects of $\mathrm{N}$ management practices with irrigation on wheat and maize crop, nitrogen fertilizers were added before or after irrigation as a three sources of $\mathrm{N}$ (urea, ammonium nitrate and ammonium sulfate) on vegetative growth, production of yields, NPK content in grains of both wheat and maize as well as nitrogen recovery. The treatments included four doses from recommended dose $(0,60,80$ and $100 \%)$. The $N$ was splitted into three doses $(50 \%$ at sowing $+25 \%$ at maximum tillering $+25 \%$ at spike initiation) for wheat crop. wterever, the $\mathrm{N}$ was applied at four splits dose ( at third leaf stage, ninth leaf stage, tasseling and milking stage) for maize crop. Results of indicated that, application of nitrogen at high er doses after irrigation led to increasing vegetation growth of both wheat and maize plants. Also, the same treatment produced the highest values of straw, grain yields, biological yield and harvest index of both wheat and maize compared to the other treatments. Macronutrients (N,P and $\mathrm{K}$ ) uptake, and this addition of nitrogen fertilizers at high dose produced the highest values of macronutrients uptake by both grains of wheat and maize compared to the other treatments. Generally, nitrogen application after irrigation resulted in the highest values of nitrogen recovery compared with the nitrogen application before irrigation. Hence, it could be concluded that the best results were obtained when nitrogen applied after irrigation with both wheat and maize crops.
\end{abstract}

Key words: Irrigation, Nitrogen fertilizers, Nitrogen Recovery and Wheat \& Maize

\section{INTRODUCTION}

Nitrogen is a major important essential nutrient because it plays an important role for plant growth and development. Thus the application of the appropriate source, rate of nitrogen fertilizer was the necessary of increasing grain yield, enhancing nitrogen uptake as well as use efficiency (Fresew et al., 2018). Nitrogen can be lost through leaching, runoff, denitrification and ammonia volatilization. Excess of nitrogen supply respect to the plant demand can lead to nitrogen losses, especially in the form of nitrate $\left(\mathrm{NO}_{3}{ }^{-}\right)$, dissolved in leaching water. $A$ combination of careful irrigation and nitrogen organization is needed to improve the uptake efficiency and to minimize potential $\mathrm{N}$ leaching. So, formulation of water and nitrogen based best management practices are required in this time to balance application and requirements of these two important factors to sustain crop productivity without damaging the environment. However, irrigation water applied at levels exceeding crop needs through conventional irrigation method is among the major reasons for increased $N$ leaching losses (Gheysari et al., 2009). The used surface irrigation which is common farming practice in the old land in Egypt caused $\mathrm{NO}_{3}{ }^{-}$transport to deeper soil layers. Also, crop production systems that optimize yield, reduce $\mathrm{N}$ loss and improve $\mathrm{N}$ uptake and WUE are 
desirable. $\mathrm{N}$ uptake is strongly influenced by water supply and high $\mathrm{NO}_{3}^{-}-\mathrm{N}$ leaching occurs with high rainwater and irrigation water supply (Fang, 2006) and Gärdenäs et al. (2005) concluded that fertigation applied at the beginning of an irrigation cycle tends to increase seasonal nitrate leaching and that fertigation applied at the end of an irrigation cycle tends to reduce nitrate leaching. There are many studies recommended that in order to avoid leaching of fertilizers to groundwater, the addition of $\mathbf{N}$ fertilizer with irrigation should be applied toward the end of an irrigation event. Thus the objective of this study aimed to assess the effect of different nitrogen doses and sources, combined with irrigation, on the production, NPK uptake and N-recovery with cultivation of wheat and maize crop.

\section{MATERIALS AND METHODS}

Two field experiments were conducted at in the Experimental Research Farm of Sids Agricultural Research Station, BaniSwief Governorate, Middle Egypt, during winter season 2016/2017 and summer season (2017) for wheat and maize crops, respectively. The chemical and physical characteristics of the soil of the experimental area at the depths from 0.0 to $30 \mathrm{~cm}$ were determined before conducting the experiment, according to methodology proposed by Rhoades (1996), Nelson and Sommers (1996). The main some soil characteristics for the experiment area are presented in Table 1.

The experiment was arranged in designing a segmented plot of land with three replicates, with a net size of $3.5 \times 3$ $\mathrm{m}$. Major plots of land have two methods of fertilization. The first method was irrigation after adding nitrogen fertilizers while the second method was the addition of nitrogen fertilizers after the end of direct irrigation, direct treatments and $\mathrm{N}$ rates of sub-land. Nitrogen sources were assigned to the sub-blocks as ammonium nitrate ( $\mathrm{AM}, 33 \% \mathrm{~N})$, urea $(U, 46.5 \% N)$ and ammonium sulfate (AS, $20.6 \% \mathrm{~N})$. While the nitrogen levels were allocated to sub-lands such as (0 control), $(60 \%$ of the recommended dose), ( $80 \%$ of the recommended dose) and $(100 \%$ of the recommended dose) which are $75 \%$ of the wheat in the winter season 2016/2017 and maize. 125 units of nitrogen in summer, 2017 consecutive season.

\section{Agronomic practics:-}

Wheat grains (variety, Bani-Swief 5) were sown at 15 November 2016 at rate of $60 \mathrm{~kg} \mathrm{fed}^{-1}$. After harvesting of wheat crop the land preparation was performed to cultivate maize grains (three cross321 hyprid) that planted in designated treatment plots. The row as the distance was $60 \mathrm{~cm}$ as well as plant to plant distance $25 \mathrm{~cm}$. Basal doses of $P$ at rates of $\left(30 \mathrm{~kg} \mathrm{P}_{2} \mathrm{O}_{5}\right.$ fed $\left.^{-1} \& 45 \mathrm{~kg} \mathrm{P}_{2} \mathrm{O}_{5} \mathrm{fed}^{-1}\right)$ and $\mathrm{K}$ at rates of $\left(24 \mathrm{~kg} \mathrm{~K}_{2} \mathrm{O} \mathrm{fed}^{-1} \& 48 \mathrm{~kg}\right.$ $\mathrm{K}_{2} \mathrm{O}$ fed. ${ }^{-1}$ ), respectively for wheat and maize were applied in the form of calcium superphosphate $\left(\mathrm{P}_{2} \mathrm{O}_{5} \quad 15 \%\right)$ and potassium sulfate $\left(\mathrm{K}_{2} \mathrm{O} \quad 48 \%\right)$, respectively. The $\mathrm{N}$ was splitted into three doses $(50 \%$ at sowing $+25 \%$ at maximum tillering $+25 \%$ at spike initiation) for wheat crop. However, the N was spliited into four doses (thid leaf stage, ninth leaf stage, tasseling and milking stage) for maize crop.

For wheat crop at full maturity, agronomic parameters including plant height $(\mathrm{cm})$, grain weight per spike $(\mathrm{g})$, 1000 grain weight (g.) and wheat grain yield (ton fed. ${ }^{-1}$ ), straw yield (ton fed..$^{-1}$ ), biological yield (ton fed. ${ }^{-1}$ ) and harvest index, while, agronomic parameters of maize crop, plant height $(\mathrm{cm})$, ear weight (g), No of rows per ear, weight of 100 greains and No of grains per row and production of grain yield (ton fed.- ${ }^{-1}$ ), straw yield (ton fed. ${ }^{-1}$ ), biological yield 
(ton fed. ${ }^{-1}$ ) and harvest index. Plant samples were collected and dried at $70^{\circ} \mathrm{C}$ until constant weight and wet digested using a mixture of $\mathrm{HClO}_{4}$ and $\mathrm{H}_{2} \mathrm{SO}_{4}$ for determining some nutrients NPK" (Piper, 1950). The data statistically analyzed using MSTAT computer software, according to Fisher's Analysis of Variance Technique and significant means were separated using Least Significant Difference (LSD) Test at $5 \%$ probability level.

\section{RESULTS AND DISCUSSION}

Effect of application methods, nitrogen sources and splitting nitrogen dose on vegetative growth characters of both wheat and maize crops:

The results in Table (2) revealed that the application methods of nitrogen with irrigation were significantly increased the vegetation growth of wheat and maize crops. For wheat plants, the application of $\mathbf{N}$ after irrigation caused the maximum values of plant height $(\mathrm{cm})$, grain weight/spike and weight of 1000 grains (g) $(46.92 \mathrm{~cm}, 2.41 \mathrm{~g}$ and $45.94 \mathrm{~g})$, respectively. Whereas adding $\mathrm{N}$ fertilizers before irrigation achieved the minimum values for plant height $(\mathrm{cm})$, grain weight/spike and weight of 1000 grains (g) $(41.77 \mathrm{~cm}, 2.25 \mathrm{~g}$ and $42.08 \mathrm{~g})$, respectively. These results were expected because the application of nitrogen fertilizers after irrigation was retarded the loss of both ammonia by volatilization and nitrate by leaching. As shown in Table (2) comparison of the different doses of $\mathbf{N}$ fertilizers on the vegetative growth of wheat plants, as can be observed the increase in the $\mathrm{N}$ doses recorded the highest values of vegetative growth $(47.81 \mathrm{~cm}, 2.50 \mathrm{~g}$ and $45.75 \mathrm{~g})$, compared with the low doses and control $(43.57 \mathrm{~cm}, 2.21 \mathrm{~g}$ and 43.64$)$ and $(36.20$ $\mathrm{cm}, 2.16 \mathrm{~g}$ and $40.68 \mathrm{~g}$ ), respectively. The application of urea produced the significant highest average of the vegetative growth of wheat plants followed by AS and AN. In the case of interaction between the application nitrogen methods and different nitrogen sources with nitrogen doses, the data in Table (2) indicted that the maximum plant height $(51.20 \mathrm{~cm})$ was recorded in treatment fertilized by urea with the highest dose after irrigation. However, the maximum values of grain weight/spike and weight of 1000 grains $(2.68 \mathrm{~g}$ and $48.94 \mathrm{~g})$ are found in treatment fertilized by ammonium sulfate. Abd-El-Fattah and Sorial (2000). Stated that increasing nitrogen levels led to increase the cytokinins and gibberellins which improving cell division and cell enlargement and thus increased vegetative growth. Concerning to vegetative growth of maize crop, data presented in Table (2) show significant differences in vegetative growth; plant height (cm), ear weight (g), No. of rows/ear, weight of 100 grain (g) and No. of grain/row). The highest values of vegetative growth were attained with application of nitrogen fertilizers after irrigation.

Table (1): Some chemical and physical properties of studied soil.

\begin{tabular}{|c|c|c|c|c|c|c|c|c|c|c|}
\hline \multicolumn{11}{|c|}{ Some chemical properties of soil } \\
\hline \multirow{2}{*}{$\begin{array}{c}\text { Depth } \\
\text { (cm) }\end{array}$} & \multirow{2}{*}{$\begin{array}{c}E C \\
\mathrm{dSm}^{-1}\end{array}$} & \multirow{2}{*}{$\begin{array}{c}\mathrm{PH} \\
(1: 2.5) \\
\end{array}$} & \multicolumn{4}{|c|}{ Soluble cations (meq/L) } & \multicolumn{4}{|c|}{ Soluble Anions (meq/L) } \\
\hline & & & $\mathrm{K}^{+}$ & $\mathrm{Na}^{+}$ & $\mathbf{M g}^{++}$ & $\mathrm{Ca}^{++}$ & $\mathrm{CO}_{3}$ & $\mathrm{HCO}_{3}{ }^{-}$ & $\mathrm{CL}^{-}$ & $\mathrm{SO}_{4}^{--}$ \\
\hline $0-30$ & 1.15 & 7.9 & 0.15 & 5.31 & 1.45 & 4.64 & --- & 3.60 & 5.58 & 2.37 \\
\hline \multicolumn{11}{|c|}{ Some physical properties of soil } \\
\hline \multirow{2}{*}{$\begin{array}{c}\text { Sand } \\
(\%)\end{array}$} & \multirow{2}{*}{$\begin{array}{l}\text { Silt } \\
(\%)\end{array}$} & \multirow{2}{*}{$\begin{array}{l}\text { Clay } \\
(\%)\end{array}$} & \multirow{2}{*}{\multicolumn{2}{|c|}{ Texture }} & \multirow{2}{*}{$\begin{array}{l}\text { OM } \\
(\%)\end{array}$} & \multirow{2}{*}{$\begin{array}{c}\mathrm{CaCO}_{3} \\
(\%)\end{array}$} & \multicolumn{4}{|c|}{ Available nutrients (mg/Kg Soil) } \\
\hline & & & & & & & & & $\mathbf{P}$ & $\mathrm{K}$ \\
\hline 9.14 & 24.37 & 66.50 & Clay & & 60 & 3.54 & & 5.0 & 0.47 & 131.80 \\
\hline
\end{tabular}


M.S. Awaad, et al.,

Table (2): Effect of application method, nitrogen sources and nitrogen dose and on vegetative growth characters of both wheat and maize crops

\begin{tabular}{|c|c|c|c|c|c|c|c|c|c|c|}
\hline \multirow[b]{2}{*}{$\begin{array}{c}\text { Application } \\
\text { of } N+ \\
\text { irrigation }\end{array}$} & \multirow[b]{2}{*}{$\begin{array}{c}\text { Sources of } N \\
\text { fertilizer }\end{array}$} & \multirow[b]{2}{*}{$\begin{array}{c}\text { Rates of } \mathrm{N} \text { as } \% \\
\text { the } \\
\text { Recommended } \\
\text { dose }\end{array}$} & \multicolumn{3}{|c|}{ Wheat } & \multicolumn{5}{|c|}{ Maize } \\
\hline & & & \begin{tabular}{|c} 
Plant \\
height \\
$(\mathrm{cm})$
\end{tabular} & $\begin{array}{l}\text { Grains } \\
\text { Weight } \\
\text { I Spike }\end{array}$ & $\begin{array}{l}\text { Weight } \\
\text { of } 1000 \\
\text { Grain } \\
\text { (g) }\end{array}$ & $\begin{array}{c}\text { Plant } \\
\text { height } \\
\text { (cm) }\end{array}$ & $\begin{array}{c}\text { Ear } \\
\text { weight }\end{array}$ & $\begin{array}{c}\text { No. of } \\
\text { rows } \\
\text { lear }\end{array}$ & $\begin{array}{c}\text { Weight } \\
\text { of } 100 \\
\text { grain } \\
\text { (g) }\end{array}$ & $\begin{array}{l}\text { No. of } \\
\text { grain } \\
\text { Irow }\end{array}$ \\
\hline \multirow{14}{*}{$\begin{array}{l}\mathrm{N} \text { Before } \\
\text { Irrigation }\end{array}$} & \multirow{4}{*}{ Urea } & 0 & 36.2 & 2.16 & 40.68 & 173.00 & 86.00 & 12.27 & 28.15 & 43.50 \\
\hline & & 60 & 42.3 & 2.2 & 41.37 & 184.00 & 100.00 & 13.67 & 30.79 & 46.37 \\
\hline & & 80 & 45.5 & 2.29 & 42.07 & 188.00 & 104.00 & 14.13 & 31.63 & 47.31 \\
\hline & & 100 & 46.15 & 2.4 & 43.3 & 195.00 & 112.00 & 14.67 & 32.77 & 48.44 \\
\hline & \multicolumn{2}{|c|}{ mean } & 42.54 & 2.26 & 41.86 & 185.00 & 100.50 & 13.69 & 30.84 & 46.41 \\
\hline & \multirow{4}{*}{$\begin{array}{c}\text { Ammonium } \\
\text { Nitrate }\end{array}$} & 0 & 36.2 & 2.16 & 40.68 & 173.00 & 86.00 & 12.27 & 28.15 & 43.50 \\
\hline & & 60 & 40.9 & 2.18 & 41.73 & 183.00 & 103.00 & 13.47 & 30.52 & 46.67 \\
\hline & & 80 & 42.2 & 2.14 & 41.94 & 187.00 & 105.00 & 13.87 & 32.02 & 47.57 \\
\hline & & 100 & 43.5 & 2.16 & 43.3 & 193.00 & 108.00 & 14.53 & 32.50 & 48.35 \\
\hline & \multicolumn{2}{|c|}{ Mean } & 40.7 & 2.16 & 41.91 & 184.00 & 100.50 & 13.54 & 30.80 & 46.52 \\
\hline & \multirow{4}{*}{$\begin{array}{c}\text { Ammonium } \\
\text { sulfate }\end{array}$} & 0 & 36.2 & 2.16 & 40.68 & 173.00 & 86.00 & 12.27 & 28.15 & 43.50 \\
\hline & & 60 & 42.3 & 2.19 & 41.94 & 184.00 & 101.00 & 13.60 & 31.11 & 46.76 \\
\hline & & 80 & 43.9 & 2.36 & 43.5 & 190.00 & 104.00 & 14.00 & 32.58 & 48.20 \\
\hline & & 100 & 45.9 & 2.64 & 43.76 & 197.00 & 113.00 & 14.67 & 33.05 & 49.05 \\
\hline & \multicolumn{2}{|c|}{ Mean } & 42.08 & 2.34 & 42.47 & 186.00 & 101.00 & 13.64 & 31.22 & 46.88 \\
\hline \multirow{15}{*}{$\begin{array}{c}\text { N After } \\
\text { Irrigation }\end{array}$} & \multirow{4}{*}{ Urea } & 0 & 36.2 & 2.16 & 40.68 & 173.00 & 86.00 & 12.27 & 28.15 & 43.50 \\
\hline & & 60 & 45.8 & 2.25 & 45.15 & 186.00 & 103.00 & 14.13 & 31.93 & 47.93 \\
\hline & & 80 & 50.8 & 2.0 & 45.99 & 192.00 & 107.00 & 15.02 & 32.62 & 48.74 \\
\hline & & 100 & 51.2 & 2.45 & 46.38 & 198.00 & 113.00 & 15.20 & 32.85 & 49.07 \\
\hline & \multicolumn{2}{|c|}{ mean } & 46 & 2.22 & 44.55 & 187.25 & 102.25 & 14.16 & 31.39 & 47.31 \\
\hline & \multirow{4}{*}{$\begin{array}{c}\text { Ammonium } \\
\text { Nitrate }\end{array}$} & 0 & 36.2 & 2.16 & 40.68 & 173.00 & 86.00 & 12.27 & 28.15 & 43.50 \\
\hline & & 60 & 45.3 & 2.2 & 45.82 & 185.00 & 100.00 & 14.13 & 31.73 & 48.10 \\
\hline & & 80 & 47.5 & 2.46 & 46.95 & 190.00 & 107.00 & 14.80 & 32.59 & 48.50 \\
\hline & & 100 & 49.4 & 2.64 & 48.84 & 196.00 & 110.00 & 15.20 & 32.87 & 49.18 \\
\hline & \multicolumn{2}{|c|}{ Mean } & 44.6 & 2.37 & 45.57 & 186.00 & 100.75 & 14.10 & 31.34 & 47.32 \\
\hline & \multirow{4}{*}{$\begin{array}{c}\text { Ammonium } \\
\text { sulfate }\end{array}$} & 0 & 36.2 & 2.16 & 40.68 & 173.00 & 86.00 & 12.27 & 28.15 & 43.50 \\
\hline & & 60 & 44.8 & 2.23 & 45.84 & 187.00 & 102.00 & 14.40 & 31.74 & 47.86 \\
\hline & & 80 & 48.18 & 2.55 & 47.98 & 196.00 & 105.00 & 14.80 & 32.85 & 48.81 \\
\hline & & 100 & 50.7 & 2.68 & 48.94 & 200.00 & 114.00 & 15.33 & 33.67 & 49.34 \\
\hline & \multicolumn{2}{|c|}{ Mean } & 44.97 & 2.41 & 45.86 & 189.00 & 101.75 & 14.20 & 31.60 & 47.38 \\
\hline \multirow{7}{*}{ LSD. at .05} & \multicolumn{2}{|r|}{$A=$} & 10.39 & 0.2103 & 9.8759 & \begin{tabular}{|l}
7.348 \\
\end{tabular} & 2.787 & 1.6233 & 6.813 & 2.232 \\
\hline & \multicolumn{2}{|r|}{$B=$} & 0.73 & 0.0906 & 0.6289 & 1.733 & 2.237 & 0.2985 & 4.293 & 0.353 \\
\hline & \multicolumn{2}{|r|}{$C=$} & 0.718 & 0.1053 & 0.6282 & 3.041 & 2.630 & 0.3515 & 4.279 & 0.263 \\
\hline & \multicolumn{2}{|r|}{$A B$} & 0.974 & 0.1209 & 0.939 & 2.311 & 2.984 & 0.3982 & 5.728 & 0.471 \\
\hline & & $A C$ & 4.86 & 0.1724 & 4.3788 & 3.633 & 1.840 & 0.7488 & 5.071 & 1.169 \\
\hline & & BC & 2.165 & 0.2597 & 1.2871 & 3.082 & 3.801 & 0.2096 & 7.307 & 2.442 \\
\hline & & $A B C$ & 10.39 & 0.2103 & 9.8759 & 7.348 & 2.787 & 1.6233 & 6.813 & 2.232 \\
\hline
\end{tabular}




\section{Straw, grains, Biological yield and Harvest index of wheat:}

Data presented in Table (2) indicated that the different nitrogen sources significantly affected the vegetative growth of maize crop i.e., plant height (cm), ear weight g, No. of rows/ear, weight of 100 grain (g) and No. of grain/row. The plants fertilized with either urea or ammonium sulfate gave the similar values of the vegetative growth. On the other hand and at the same time, these values were the highest compared to the plant received ammonium nitrate. Different nitrogen doses significantly affected the vegetative growth, the high nitrogen doses increased all the values of parameters vegetative growth parameters $(196.50 \mathrm{~cm} 111.67 \mathrm{~g}, \quad 14.93$, $32.95 \mathrm{~g}$ and 48.91$)$ for plant height $(\mathrm{cm})$, Ear weight $\mathrm{g}$, No. of rows/ear, weight of 100 grain (g) and No. of grain/row, respectively. Concerning the interaction amang the application of nitrogen methods different nitrogen sources with nitrogen doses, data in Table (2) revealed that the highest values of vegetative growth ware obtained with the plants received the high doses of nitrogen fertilizer as ammonium sulfate when it was applied after irrigation. A study conducted in the United States Holcomb et al., (2011). Who reported that a reduction by $90 \%$ of $\mathrm{NH}_{3}$ volatilization enduced with applying $15 \mathrm{~mm}$ irrigation although no reduction in volatilization was observed in other studies in the southeastern region of Brazil, by applying $28 \mathrm{~mm}$ irrigation after $\mathrm{N}$ fertilization. Khan et al., (2005). Poimted out that higher cobs plant $^{-1}, 1000$ grain weight, number of grains cob $^{-1}$ and grain yield with $120 \mathrm{~kg} \mathrm{~N} \mathrm{ha}^{-1}$..

Data in Table (3) presented that there were no significant influence between the two application of nitrogen and different nitrogen sources on straw, grains, biological yield and harvest index. However, the relative values of increase were $(50.73 \%, 58.17 \%, 53.68 \%$ and 2.99 $\%)$, respectively due to nitrogen application compared to the control treatment, The plants received the high doses of nitrogen recorded the highest values of straw, grains, biological yield compared at the other one. The relative precent of increasing were, $77 \%, 86 \%$, $81 \%$ and $3 \%$ for straw, grains, biological yield and harvest index, respectively compared to the control referred, The interaction amang the method of $\mathbf{N}$ application, sources and doses, showed the maximum values of straw, grains, biological yield as aresults of the due combinations of $\mathbf{N}$ after irrigation at the high dose with $\mathbf{N}$ as ammonium nitrate. Mekonen (2005). Reported that a day to heading was significantly delayed when $\mathrm{N}$ fertilizer was applied at the highest rate for wheat and barley production compared to the lowest rate.On the other hand maximum harvest index (41.29\%) was recorded with the application of $\mathbf{1 0 0}$ $\%$ of $\mathrm{N}$ application as urea after irrigation followed by $100 \%$ of $N$ application as ammonium sulfate after irrigation (41.19\%). Minimum harvest index $(39.60 \%)$ was recorded in the control plot.

Data of maize (Table 3) demoted that effect of method of $\mathrm{N}$ application with irrigation was non-significant, however, the addition of $\mathrm{N}$ increased the values of regarding straw, grains, biological yield and harvest index by about (61.96\%, $106.13 \%, 78.10 \%$ and $15.73 \%$ ) relative to the control, Nitrogen doses appeared a significant effects on straw, grains, biological yield and harvest index. Likewise, the high dose of $\mathbf{N}$ application caused the highest relative increase by (97.76\%, $165.20 \%, 122.48 \%$ and $19.23 \%)$ compared to control. Interactive effect of $\mathbf{N}$ applications with irrigation, nitrogen sources and nitrogen doses was also significant (Table 3). The maximum values of straw, grains, biological yield (5.77 tons /fed. ${ }^{-1}, 3.90$ ton $/$ Ifed $^{-1}$ and 9.67 
M.S. Awaad, et al.,

ton $/ \mathrm{fed}^{-1}$ ) were achieved with the combination of $\mathrm{N}$ application in the form of ammonium nitrate after irrigation at $100 \%$ dose from recommended dose. While minimum (3.70 ton $/ \mathrm{fed}^{-1}, 2.44$ ton
Ifed. $.^{-1}, 6.14$ ton Ifed..$^{-1}$ and $39.74 \%$ ) interactive response was found in $\mathrm{N}$ application in the form of urea before irrigation at $60 \%$ dose from recommended dose treatments.

Table (3): Straw, grain yields, biological yield and harvest index of both wheat and maize as ffected by nitrogen sources, nitrogen doses and methods of application.

\begin{tabular}{|c|c|c|c|c|c|c|c|c|c|c|}
\hline \multirow[b]{2}{*}{$\begin{array}{c}\text { Application } \\
\text { of } \mathrm{N}+ \\
\text { irrigation }\end{array}$} & \multirow[b]{2}{*}{$\begin{array}{l}\text { Sources of } \\
\mathrm{N} \text { fertilizer }\end{array}$} & \multirow{2}{*}{$\begin{array}{c}\text { Rates of } \mathrm{N} \text { as } \\
\% \text { the } \\
\text { Recommended } \\
\text { dose }\end{array}$} & \multicolumn{4}{|c|}{ Wheat } & \multicolumn{4}{|c|}{ Maize } \\
\hline & & & $\begin{array}{c}\text { Straw } \\
\text { (ton/fed.) }\end{array}$ & $\begin{array}{c}\text { Grains } \\
\text { (ton/fed.) }\end{array}$ & $\left|\begin{array}{c}\text { Biological } \\
\text { yield } \\
\text { (ton/fed.) }\end{array}\right|$ & $\begin{array}{c}\text { Harvest } \\
\text { index } \\
(\%)\end{array}$ & $\begin{array}{c}\text { Straw } \\
\text { (ton/fed.) }\end{array}$ & $\begin{array}{c}\text { Grains } \\
\text { (ton/fed.) }\end{array}$ & \begin{tabular}{|c|} 
Biological \\
yield \\
(ton/fed.)
\end{tabular} & $\begin{array}{l}\text { Harvest } \\
\text { index } \\
(\%)\end{array}$ \\
\hline \multirow{14}{*}{$\begin{array}{l}\mathrm{N} \text { Before } \\
\text { Irrigation }\end{array}$} & \multirow{4}{*}{ Urea } & 0 & 3.20 & 2.10 & 5.30 & 39.62 & 2.16 & 1.25 & 3.41 & 36.66 \\
\hline & & 60 & 4.96 & 3.45 & 8.41 & 41.02 & 3.70 & 2.44 & 6.14 & 39.74 \\
\hline & & 80 & 5.15 & 3.80 & 8.95 & 42.46 & 3.75 & 3.01 & 6.76 & 44.53 \\
\hline & & 100 & 5.52 & 3.84 & 9.36 & 41.03 & 3.98 & 3.25 & 7.23 & 44.95 \\
\hline & \multicolumn{2}{|c|}{ mean } & 4.71 & 3.30 & 8.01 & 41.03 & 3.40 & 2.49 & 5.89 & 41.47 \\
\hline & \multirow{4}{*}{$\begin{array}{c}\text { Ammonium } \\
\text { Nitrate }\end{array}$} & 0 & 3.20 & 2.10 & 5.30 & 39.62 & 2.16 & 1.25 & 3.41 & 36.66 \\
\hline & & 60 & 5.36 & 3.50 & 8.86 & 39.50 & 3.65 & 2.62 & 6.27 & 41.79 \\
\hline & & 80 & 5.26 & 3.78 & 9.04 & 41.81 & 3.98 & 2.95 & 6.93 & 42.57 \\
\hline & & 100 & 5.70 & 3.86 & 9.56 & 40.38 & 4.21 & 3.29 & 7.50 & 43.87 \\
\hline & \multicolumn{2}{|c|}{ Mean } & 4.90 & 3.31 & 8.19 & 40.26 & 3.50 & 2.53 & 6.03 & 41.22 \\
\hline & \multirow{4}{*}{$\begin{array}{c}\text { Ammonium } \\
\text { sulfate }\end{array}$} & 0 & 3.20 & 2.10 & 5.30 & 39.62 & 2.16 & 1.25 & 3.41 & 36.66 \\
\hline & & 60 & 5.00 & 3.50 & 8.50 & 41.18 & 3.75 & 2.69 & 6.44 & 41.77 \\
\hline & & 80 & 5.50 & 3.85 & 9.35 & 41.18 & 3.88 & 3.16 & 7.04 & 44.89 \\
\hline & & 100 & 5.75 & 3.85 & 9.60 & 39.90 & 4.34 & 3.34 & 7.68 & 43.49 \\
\hline & \multicolumn{2}{|c|}{ Mean } & 4.86 & 3.36 & 8.20 & 40.08 & 3.53 & 2.61 & 6.22 & 41.70 \\
\hline \multirow{14}{*}{$\begin{array}{c}\text { N After } \\
\text { Irrigation }\end{array}$} & \multirow{4}{*}{ Urea } & 0 & 3.20 & 2.10 & 5.30 & 39.62 & 2.16 & 1.25 & 3.41 & 36.66 \\
\hline & & 60 & 4.98 & 3.50 & 8.48 & 41.27 & 3.84 & 2.80 & 6.64 & 42.17 \\
\hline & & 80 & 5.08 & 3.79 & 8.87 & 42.73 & 4.11 & 3.06 & 7.17 & 42.68 \\
\hline & & 100 & 5.60 & 3.98 & 9.50 & 41.89 & 4.36 & 3.31 & 7.67 & 43.16 \\
\hline & \multicolumn{2}{|c|}{ mean } & 4.72 & 3.34 & 8.04 & 41.29 & 3.62 & 2.61 & 6.23 & 41.17 \\
\hline & \multirow{4}{*}{$\begin{array}{c}\text { Ammonium } \\
\text { Nitrate }\end{array}$} & 0 & 3.20 & 2.10 & 5.30 & 39.62 & 2.16 & 1.25 & 3.41 & 36.66 \\
\hline & & 60 & 5.16 & 3.50 & 8.66 & 40.42 & 3.74 & 2.66 & 6.40 & 41.56 \\
\hline & & 80 & 5.47 & 3.79 & 9.26 & 40.93 & 3.49 & 3.06 & 6.55 & 46.72 \\
\hline & & 100 & 5.77 & 3.90 & 9.67 & 40.33 & 4.32 & 3.32 & 7.64 & 43.46 \\
\hline & \multicolumn{2}{|c|}{ Mean } & 4.90 & 3.32 & 8.22 & 40.39 & 3.43 & 2.57 & 6.00 & 42.10 \\
\hline & \multirow{4}{*}{$\begin{array}{c}\text { Ammonium } \\
\text { sulfate }\end{array}$} & 0 & 3.20 & 2.10 & 5.30 & 39.62 & 2.16 & 1.25 & 3.41 & 36.66 \\
\hline & & 60 & 5.03 & 3.50 & 8.53 & 41.03 & 3.89 & 2.77 & 6.66 & 41.59 \\
\hline & & 80 & 5.52 & 3.80 & 9.32 & 40.77 & 3.57 & 3.18 & 6.75 & 47.11 \\
\hline & & 100 & 5.64 & 3.95 & 9.59 & 41.19 & 4.42 & 3.38 & 7.80 & 42.17 \\
\hline & \multicolumn{2}{|c|}{ Mean } & 4.85 & 3.34 & 8.19 & 40.65 & 3.51 & 2.65 & 6.16 & \begin{tabular}{|l|}
42.17 \\
\end{tabular} \\
\hline \multirow{7}{*}{ LSD. at .05 } & \multicolumn{2}{|r|}{$A=$} & 0.5194 & 0.0380 & 0.27703 & 0.2593 & 0.1264 & 0.2010 & 0.4206 & 1.2390 \\
\hline & \multicolumn{2}{|r|}{$B=$} & 0.0887 & 0.0491 & 0.06232 & 0.1900 & 0.0486 & 0.0314 & 0.1510 & 0.3620 \\
\hline & \multicolumn{2}{|r|}{$C=$} & 0.0764 & \begin{tabular}{|l|}
0.0426 \\
\end{tabular} & 0.23382 & 0.1834 & 0.0650 & 0.0261 & 0.1528 & 0.2292 \\
\hline & \multicolumn{2}{|r|}{$A B$} & 0.1184 & 0.0655 & 0.08313 & 0.2535 & 0.0648 & 0.0418 & 0.2015 & 0.4829 \\
\hline & & AC & 0.6293 & 0.0570 & 0.36354 & 0.6483 & 0.2971 & 0.1349 & 0.2943 & 1.9364 \\
\hline & & $B C$ & 0.6955 & 0.0422 & 0.57942 & 1.3479 & 0.2559 & 0.1081 & 0.3719 & 1.8488 \\
\hline & & $\mathrm{ABC}$ & 0.9732 & 0.0407 & 0.78499 & 1.0102 & 0.4202 & 0.1815 & 0.5299 & 3.8504 \\
\hline
\end{tabular}


The effect of nitrogen addition with irrigation, nitrogen sources and dosing on the uptake of nitrogen, phosphorus and potassium in wheat grains. The data presented in Table (4) show that the values of nitrogen absorption in wheat grains were affected as a result of applying all the treatments. The addition of nitrogen fertilization after irrigation led to an increase in the value of nitrogen absorption by about $(4.81 \%)$ compared with the addition of nitrogen before irrigation, and this is due to the decrease in the percentage of moisture, the increase in nitrogen concentration, the decrease in its movement with irrigation water, ground gravity, and a longer stay in the area of root spread, which increases the capacity of plants. To be absorbed and transferred into the plant. Whereas the values of $P$ and $K$ absorbance are not great. Late application of $\mathrm{N}$ increased management flexibility by providing $\mathrm{N}$ when soil moisture was low and root uptake was minimal, so the grower could adjust fertilizer rates to improve $\mathrm{N}$ uptake and productivity.

As regarded to the effect of $\mathrm{N}$ doses, the obtained data in Table (4) point out that increasing nitrogen fertilizer doses led to a significant enhansment increase in $\mathrm{N}, \mathrm{P}$ and $\mathrm{K}$ uptake by grains of wheat crop compared to the control. The values of relative increase were $(158.68 \%$, $126.72 \%$ and $102.84 \%$ ) for $N, P$ and $K$ uptake, respectively due to application the high dose of $\mathrm{N}$ compared to control.
Data presented in Table (4) elucidate that the interaction between application nitrogen methods with irrigation and nitrogen sources at different doses resulted in a significant effect on $N, P$ and $K$ uptake by grains of wheat plants. The highest value of $\mathrm{N}$-uptake was achieved with application of $\mathrm{N}$ as ammonium nitrate after irrigation at the high or dose of nitrogen, however, the highest values of $P$ and $K$ uptake were obtained with the application of $\mathrm{N}$ as a urea after irrigation at the high dose.

Application of $\mathbf{N}$ augmented increased the uptake of $\mathrm{N}$ which might be attributed to higher $\mathrm{N}$ availability for the crop. Also, in alkaline soils the $\mathrm{NH}_{3}$ volatilization from urea and ammonium sulfate is higher than from ammonium nitrate this might be the reason for the lower efficiency of urea and ammonium sulfate than ammonium nitrate that observed in the present study. These results are in agreement with findings of Fageria (2014). Who found that the application of the appropriate dose of $\mathrm{N}$ fertilizer is the means of increasing wheat grain yield, improving $\mathbf{N}$ uptake and nitrogen use efficiency. Arduini et al. (2006). Reported that increasing $N$ rates from 60 to $120 \mathrm{~kg}$ $\mathrm{ha}^{-1}$ caused an increase in grain nitrogen concentration of wheat from 1.52 to 2.28 $\%$. Arshad et al. ( 1999). Who speculated that $\mathrm{N}$ uptake and $\mathrm{N}$ recovery in wheat was significantly higher at optimum $\mathrm{NH}_{4}{ }^{+}$ , $\mathrm{N}: \mathrm{NO}_{3}: \mathrm{N}$ ratio of $50: 50$ than where $\mathrm{NH}_{4}$ or $\mathrm{NO}_{3}$ alone was used. 
M.S. Awaad, et al.,

Table (4): N. P and K uptake by grains of wheat and maize as affected by different treatments.

\begin{tabular}{|c|c|c|c|c|c|c|c|c|}
\hline \multicolumn{3}{|c|}{ Treatments } & \multicolumn{3}{|c|}{$\begin{array}{c}\text { Uptake by grain of } \\
\text { wheat }\end{array}$} & \multicolumn{3}{|c|}{$\begin{array}{c}\text { Uptake by grain of } \\
\text { maize }\end{array}$} \\
\hline \multirow[t]{2}{*}{$\begin{array}{c}\text { Application } \\
\text { of } \\
\mathrm{N}+\text { irrigation }\end{array}$} & $\begin{array}{l}\text { Sources of } \\
\mathrm{N} \text { fertilizer }\end{array}$ & $\begin{array}{l}\text { Rates of } \mathrm{N} \text { as } \\
\% \text { the } \\
\text { Recommended } \\
\text { dose }\end{array}$ & $\mathbf{N}$ & $\mathbf{P}$ & $\mathbf{K}$ & $\mathbf{N}$ & $\mathbf{P}$ & K \\
\hline & & & \multicolumn{3}{|c|}{ Wheat } & \multicolumn{3}{|c|}{ Maize } \\
\hline \multirow{14}{*}{$\begin{array}{l}\text { N Before } \\
\text { Irrigation }\end{array}$} & \multirow{4}{*}{ Urea } & 0 & 19.32 & 6.72 & 10.08 & 13.75 & 2.75 & 3.00 \\
\hline & & 60 & 36.57 & 10.01 & 15.53 & 29.28 & 3.90 & 6.10 \\
\hline & & 80 & 41.04 & 14.06 & 18.24 & 45.15 & 4.82 & 7.53 \\
\hline & & 100 & 49.54 & 13.06 & 19.97 & 42.25 & 4.23 & 9.10 \\
\hline & \multicolumn{2}{|c|}{ mean } & 36.62 & 10.96 & 15.95 & 32.61 & 3.23 & 6.43 \\
\hline & \multirow{4}{*}{$\begin{array}{l}\text { Ammonium } \\
\text { Nitrate }\end{array}$} & 0 & 19.32 & 6.72 & 10.08 & 13.75 & 2.75 & 3.00 \\
\hline & & 60 & 38.50 & 6.65 & 16.80 & 39.30 & 3.93 & 7.07 \\
\hline & & 80 & 46.87 & 12.85 & 17.77 & 38.35 & 4.72 & 7.38 \\
\hline & & 100 & 50.18 & 15.83 & 18.91 & 46.06 & 6.25 & 7.90 \\
\hline & \multicolumn{2}{|c|}{ mean } & 38.72 & 10.51 & 15.89 & 34.36 & 4.41 & 6.34 \\
\hline & \multirow{4}{*}{$\begin{array}{l}\text { Ammonium } \\
\text { sulfate }\end{array}$} & 0 & 19.32 & 6.72 & 10.08 & 13.75 & 2.75 & 3.00 \\
\hline & & 60 & 32.55 & 12.60 & 14.70 & 45.73 & 7.53 & 9.68 \\
\hline & & 80 & 45.05 & 14.63 & 19.25 & 47.40 & 12.01 & 9.16 \\
\hline & & 100 & 49.53 & 15.99 & 21.45 & 50.10 & 14.36 & 8.35 \\
\hline & & ean & 36.61 & 12.49 & 16.37 & 39.85 & 9.16 & 7.55 \\
\hline \multirow{15}{*}{$\begin{array}{l}\mathrm{N} \text { After } \\
\text { Irrigation }\end{array}$} & \multirow{4}{*}{ Urea } & 0 & 19.32 & 6.72 & 10.08 & 13.75 & 2.75 & 3.00 \\
\hline & & 60 & 44.10 & 10.15 & 14.70 & 39.20 & 6.44 & 8.68 \\
\hline & & 80 & 47.00 & 12.51 & 18.57 & 42.84 & 5.81 & 9.79 \\
\hline & & 100 & 51.34 & 16.72 & 22.69 & 52.96 & 12.91 & 11.92 \\
\hline & \multicolumn{2}{|c|}{ mean } & 40.44 & 11.52 & 16.51 & 37.19 & 6.98 & 8.35 \\
\hline & \multirow{4}{*}{$\begin{array}{l}\text { Ammonium } \\
\text { Nitrate }\end{array}$} & 0 & 19.32 & 6.72 & 10.08 & 13.75 & 2.75 & 3.00 \\
\hline & & 60 & 37.45 & 11.55 & 16.45 & 37.24 & 2.93 & 6.65 \\
\hline & & 80 & 42.83 & 13.27 & 18.19 & 42.84 & 3.98 & 9.18 \\
\hline & & 100 & 51.87 & 15.21 & 18.33 & 56.44 & 6.64 & 11.95 \\
\hline & \multicolumn{2}{|c|}{ mean } & 37.87 & 11.69 & 15.76 & 37.57 & 4.08 & 7.70 \\
\hline & \multirow{4}{*}{$\begin{array}{l}\text { Ammonium } \\
\text { sulfate }\end{array}$} & 0 & 19.32 & 6.72 & 10.08 & 13.75 & 2.75 & 3.00 \\
\hline & & 60 & 39.55 & 11.55 & 16.45 & 44.32 & 3.60 & 7.76 \\
\hline & & 80 & 49.02 & 12.54 & 18.24 & 44.52 & 4.13 & 7.95 \\
\hline & & 100 & 47.40 & 14.62 & 21.33 & 54.08 & 5.75 & 8.79 \\
\hline & \multicolumn{2}{|l|}{ mean } & 38.82 & 11.36 & 16.53 & 39.17 & 4.06 & 6.88 \\
\hline \multirow{7}{*}{\multicolumn{2}{|c|}{ LSD. at .05 }} & A & 5.069 & 0.884 & 0.779 & 7.139 & 0.598 & 3.811 \\
\hline & & B & 0.291 & 0.136 & 0.101 & 0.577 & 0.055 & 0.172 \\
\hline & & C & 0.353 & 0.155 & 0.313 & 0.385 & 0.078 & 0.177 \\
\hline & & $A B$ & 0.388 & 0.181 & 0.134 & 0.770 & 0.074 & 0.229 \\
\hline & & $A C$ & 4.215 & 0.704 & 0.625 & 5.854 & 1.951 & 3.003 \\
\hline & & BC & 4.809 & 0.827 & 2.004 & 9.128 & 2.689 & 1.509 \\
\hline & & ABC & 6.858 & 1.693 & 1.612 & 8.844 & 5.937 & 2.447 \\
\hline
\end{tabular}


Effect of application $\mathrm{N}$ with irrigation, sources of $\mathrm{N}$ and doses on $\mathrm{N}, \mathrm{P}$ and $\mathrm{K}$ uptake by grain of maize:

The effect of different nitrogen method application with irrigation at different doses and sources of nitrogen on $\mathrm{N}, \mathrm{P}$ and $K$ uptake by grains of maize were noted in Table (4). For $N, P$ and $K$ uptake by grains of maize plants, data indicated that application of nitrogen fertilizer after irrigation caused the higher $\mathrm{N}$ uptake (4.62\%) than the other method, however no significant differences were observed between $P$ and $k$ uptake. In addition the plots that received the high dose of $\mathrm{N}$ gave highest values of $\mathrm{N}, \mathrm{P}$ and $\mathrm{K}$ uptake (50.32 kg/fed., $8.36 \mathrm{~kg} / \mathrm{fed}$ and 9.67 $\mathrm{kg} / \mathrm{fed}$., respectively) compared to other doses and control treatment. Data displayed that a much greater total uptake of phosphorus by grains of maize plants in the presence of nitrogen than in the absence of nitrogen. Similarly, plots treated with $\mathrm{N}$ fertilizer as ammonium sulfate significantly promoted $\mathrm{N}, \mathrm{P}$ and $\mathrm{K}$ uptake than the other sources of $\mathrm{N}$. These results may be ascribed to the acidic influence of ammonium sulfate on minimizing th soil $\mathrm{pH}$ consoquentily raising the nutrient availbiltyin the soil and its uptake by plant. Costa et al. (2002). Reported that root length and root surface area were increased with the intermediate $\mathrm{N}$ levels as well as increase the available of nutrients however that root growth was reduced affected by both higher and lower fertilization levels. Also, it was observed an interaction between application nitrogen methods with irrigation and nitrogen sources at different doses significant affect $\mathrm{N}, \mathrm{P}$ and $K$ uptake by grains of maize. In general, with the absorption of $\mathrm{NH}_{4}{ }^{+}$by plants, the related proton released decreases the $\mathrm{pH}$ of the rhizosphere which leads to increased solubility and uptake of nutrients by the plants (Zhao et al., 2008), Gebregergis and Amare (2019). Found that application of adequate nitrogen nutrition is beneficial to improve uptakes of other nutrients, particularly $P$ and $K$ and some micronutrients.

\section{Nitrogen use efficiency ( $\mathrm{N}$-recovery)}

In relation to NUE (N-recovery) by grains of both wheat and maize crop, the Fig. (1 A) demonstrated that the $\mathrm{N}$ application after irrigation improved the nitrogen use efficiency by the plants. Also, the results indicated that, mainly excess of $\mathrm{N}$ application tends to reduce the efficiency use of plants. This is directly related to the losses by application and by limitation in the absorption of this nutrient by plants. Also, Fig.(1B) revealed that the low doses of nitrogen recorded the high $\mathrm{N}$-recovery with both $\mathrm{N}$ application with irrigation at different sources of $\mathrm{N}$ for wheat and maize crops. However, interaction between the $\mathrm{N}$ application, doses and sources are shown in (Fig. $1 \mathrm{C}$ ) indicate that urea at low dose with nitrogen application after irrigation recorded the highest values of $\mathrm{N}$-recovery compared to other treatments for both wheat and maize crops. According to Valero et al. (2005). NUE tends to decrease with the increase the fertilizer rates. Fernandes et al. (2005). In a study with six maize cultivars with different $\mathbf{N}$ doses, obtained higher values of NUE under $\mathbf{N}$ dose of $\mathbf{3 0}$ $\mathrm{kg} \mathrm{ha}^{-1}$, decrease with $\mathrm{N}$ doses increased to 90 and $180 \mathrm{~kg} \mathrm{ha}^{-1}$. Zotarelli et al. (2011). Found that the actual water requirement of plants tends to improve NUE, due to the greater control in the amount of water applied and the consequent maintenance of $\mathrm{N}$ close to their root zone, resulting in lower losses through $\mathrm{NO}_{3}^{-}$leaching. Moreover, the supply closer to the actual requirement of the crop combined to adequate fertilization through fertigation, for instance, tends to increase NUE in crops (Quemada and Gabriel, 2016). 
M.S. Awaad, et al.,

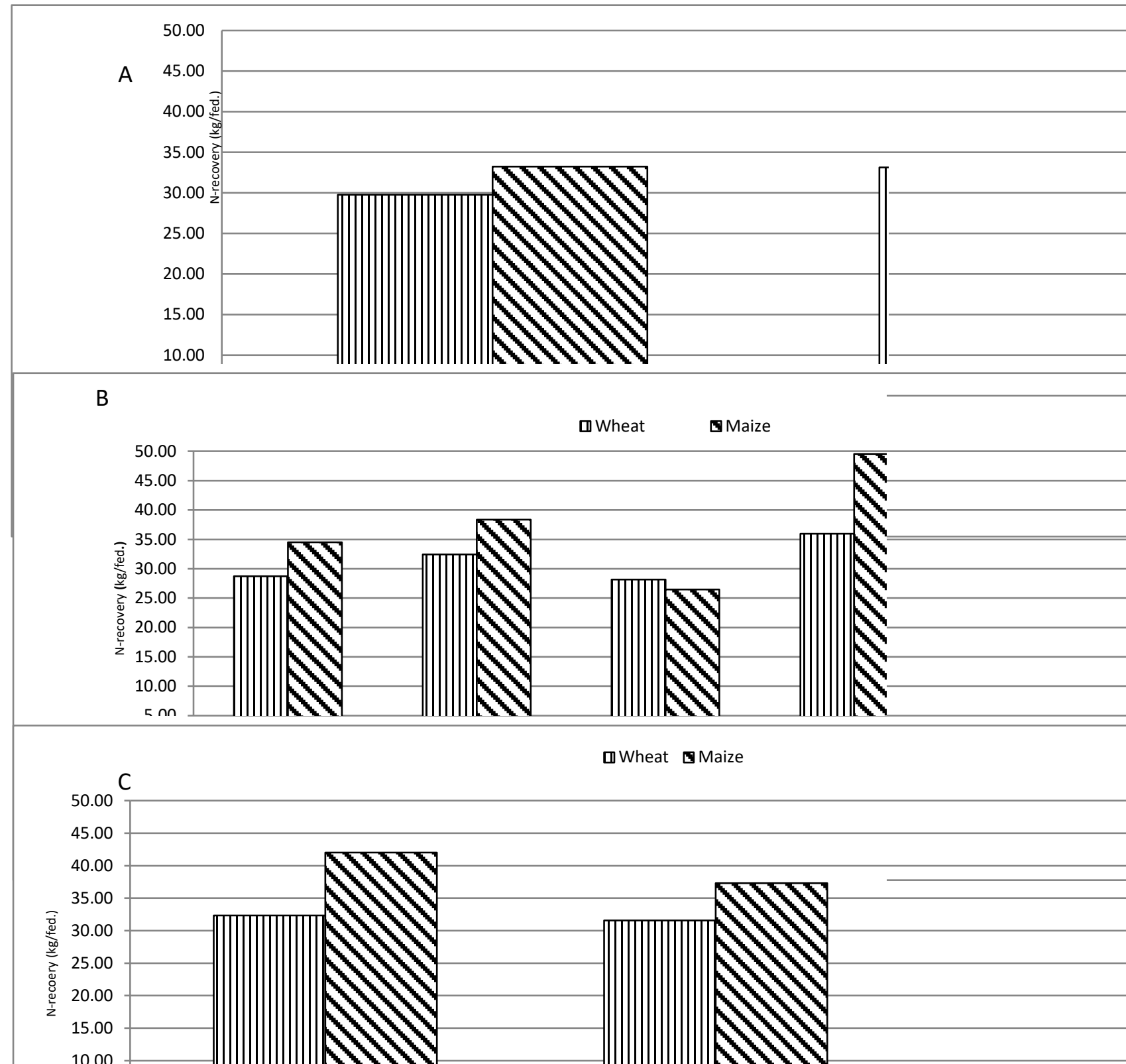

Fig. (1): Effect of nitrogen sources, nitrogen doses and methods of application on Nrecovery by grains of both wheat and maize

\section{Conclusion}

The results evidently demonstrated that the values of plant growth parameters as well as macronutrients ( $N, P$ and $K$ ) uptake by both grains of wheat and maize obtaibed when application of height dose from different nitrogen sources compared to control. Also, nitrogen application after irrigation resulted in the highest values of nitrogen use efficiency or nitrogen recovery compared to the nitrogen application before irrigation. Hence, it could be concluded that the best results were obtained when nitrogen applied after irrigation with both wheat and maize crops 


\section{REFERENCES}

Abd-El-Fattah, M.A. and M.E. Sorial (2000). Sex expression and productivity responses of summer squash to biofertilizer application under different nitrogen levels. Zagzig. J. Agric. Res., 27 (2): 255-281.

Arduini, I., Masoni A., Ercoli L. and M. Mariotti (2006). Grain yield, and dry matter and nitrogen accumulation and remobilization in wheat as affected by variety and seeding rate. Eur J. Agron; 25(4):309-18.

Arshad, M. M., S. Zia and T. Ahmad (1999). Mixed Ammonium and Nitrate Nutrition of Wheat Under Different Soil Salinity Regimes. Pakistan Journal of Biological Sciences, 2 (2): 490-493.

Costa, C., Dwyer L.M., Zhou X., Dutilleul P., Hamel C. and L.M. Reid (2002). Root morphology of contrasting maize genotypes. Agronomy Journal. 94(1): 96-101.

Fageria, N.K. (2014). Nitrogen harvest index and its association with crop yields. J Plant Nutr. 37: 795-810.

Fang, YT. (2006). Effects of nitrogen deposition on soil nitrogen processes in Dinghushan forests. pp 137. Graduate School of The Chinese Academy of Sciences, Guangzhou. (In Chinese with English abstract).

Fernandes, F. C. S., S. Buzetti, O. Arf and J. A. da C. Andrade (2005). Doses, Efficiency and Nitrogen Use by Six Maize Cultivars. Revista Brasileira de Milho e Sorgo, 4: 195-204.

Fernandes, F. C. S., S. Buzetti, O. Arf and J. A. da C. Andrade (2005). eficiência e uso de nitrogênio por seis cultivares de milho. Revista Brasileira de Milho e Sorgo, 4: 195-204.

Fresew, B., D. Nigussa, M. Adamu and T. Tamado (2018). Effect of nitrogen fertilizer rates on grain yield and nitrogen uptake and use efficiency of bread wheat (traticum aestivum L.) varieties on th vertisols of central highlands of Ethiopia. Agric \& Food Secur, 78: 1-12.

Gardenas, A.I., J.W. Hopmans, B.R. Hanson and B. J. S. imunek (2005). Two-dimensional modeling of nitrate leaching for various fertigation scenarios under micro-irrigation. Agricultural Water Management 74: 219-242

Gebregergis, Z. and M. Amare (2019). Effect of Nitrogen Fertilization on the Growth and Seed Yield of Sesame (Sesamum indicum L.) International Journal of Agronomy, Volume, Article ID 5027254, 7 pages.

Gheysari, M., S.M. Mirlatifi, M. Bannayan, M. Homaee and G. Hoogenboom (2009). Interaction of water and nitrogen on maize grown for silage. Agric. Water Manage. 96:809-821.

Holcomb, JC., DM. Sullivan, DA Horneck and GH. Clough (2011). Effect of irrigation rate on ammonia volatilization. Soil Sci. Soc. Am J., 75:2341-47.

Khan, A., A. Jan and S. Alam (2005). Effect of nitrogen and seed size on maize crop II: yield and yield components. J. Agric. Soc. Sci., 1(3): 1823.

Mekonen, A. (2005). Response and uptake of barley (Hordeum irregulare L.) to different rates of Orga-P And nitrogen fertilizers on Nitisols of Gozamin District, Ethiopia. MSc Thesis,

Nelson, D. W. and L. E. Sommers (1996). Total Carbon, Organic Carbon, and Organic Matter. International Public Inc., New York.

Piper, C. (1950). Soil and Plant Analysis. International Public Inc., New York. 
M.S. Awaad, et al.,

Quemada, M. and J. L. Gabriel (2016). Approaches for increasing nitrogen and water use efficiency simultaneously. Global Food Security, 9: 29-35.

Rhoades, J. D. (1996). Salinity: Electrical Conductivity and Total Dissolved Solids. First published: 01 January 1996.

Valero, J. A. de J., M. Maturano, A. A. Ramírez, J. T. Martín-Benito and J. F. O. Álvarez (2005). Growth and nitrogen use efficiency of irrigated maize in a semiarid region as affected by nitrogen fertilization. Spanish
Journal of Agricultural Research, 3: 134-144.

Zhao, D., M. Kane, B. Borders and M. Harrison (2008). Pine growth response to different site- preparation methods with or without post-plant herbaceous weed control on North Florida's Lower Coastal Plain. Forest Ecology and Management. 255(7): 2512-2523.

Zotarelli, L., M. D. Dukes, J. M. S. Scholberg, K. Femminella and $R$. Muñoz-Carpena (2011). Irrigation scheduling for green bell peppers using capacitance soil moisture sensors. Journal of Irrigation and Drainage Engineering, 137: 73-81. 
تأثير إضافة مصادر مختلفة من النيتروجين على محصولى القـح والذرة

محمد سعيد عواد، محمد احمد السيد الثاذلى، محمد بسيونى طه، إبراهيم محمد عبدالله

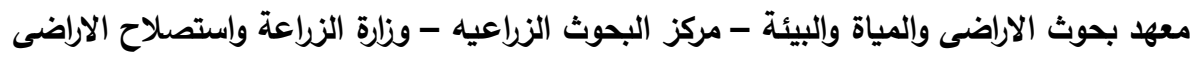

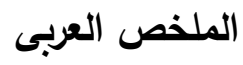

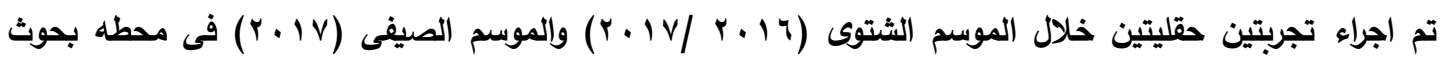

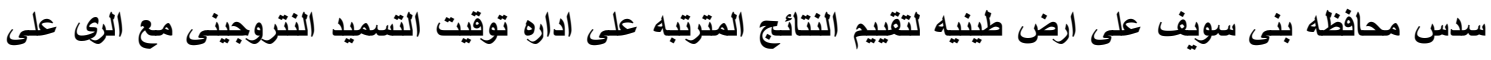

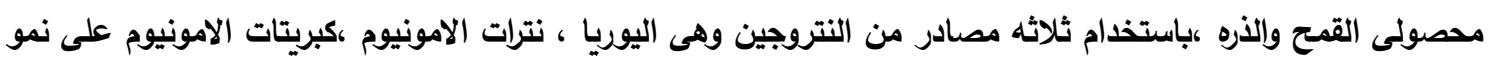
وإنتاجيه المحاصيل ومستوى العناصر فى النباتات وفى الحبوب وكفاءة امتصاص العناصر الغذائيه. وكانت معدلات

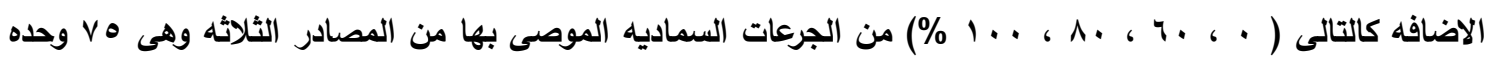

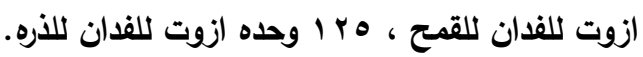

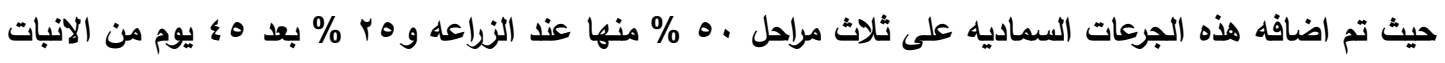

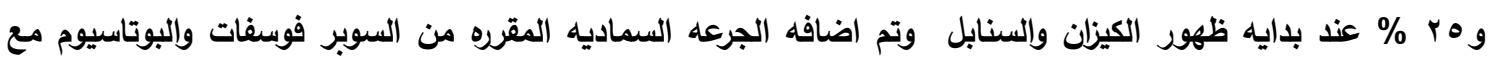
تجهيز الارض للزراعه.

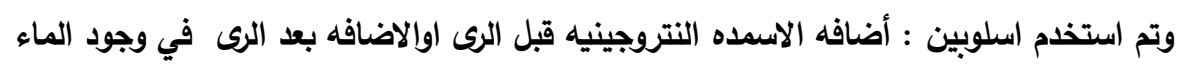

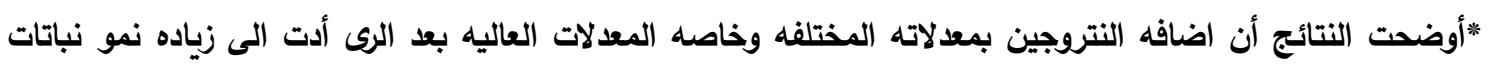
القمح والذره. * أوضحت ايضا أنه حدث زيادة فى محصول القش ومحصول الحبوب والكتلة الحيويه وبيانات النمو والمحصول لكل من

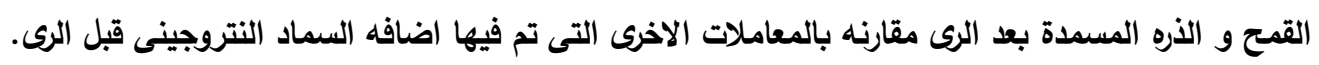

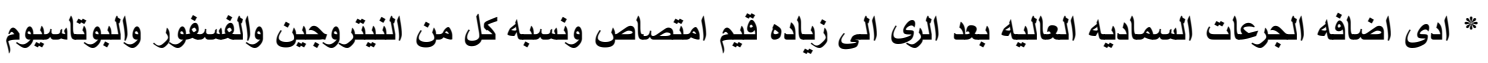

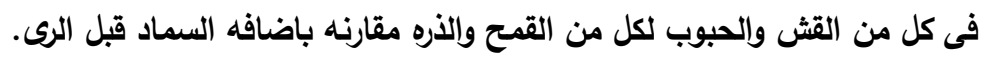

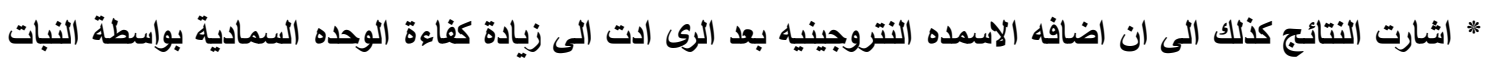

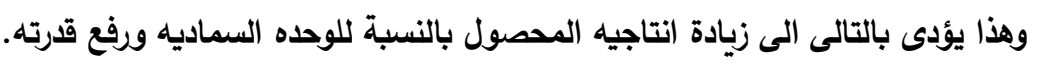

السادة المحكمين

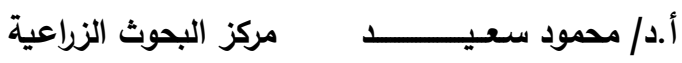

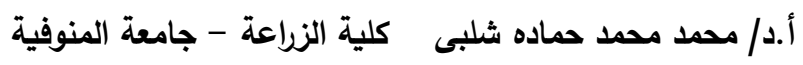

